- комплексному використанню розумових прийомів у різних комбінаціях;

- самостійному застосуванню розумових прийомів.

3. Використання багатокомпонентних завдань передбачає:

- розв’язування звичайної (готової) задачі;

- складання оберненої задачі та її розв'язання;

- складання аналогічної задачі;

- складання нової задачі, використовуючи деякі компоненти початкової задачі;

- розв’язування або складання узагальненої оцінки іншими параметрами вихідної (початкової) задачі.

4. Використання прийомів розумових дій сприяе розв'язуванню задач у такій послідовності: вихідна задача - аналогічна задача - обернена задача - задача узагальнення (або конкретизації).

Висновки. Отже, в ході дослідження нами було встановлено, що формування пізнавальної активності учнів, прагнення до відкриття нового у навчанні математики буде успішним, якщо при його організації забезпечити систематичне, цілеспрямоване, обгрунтоване й педагогічно доцільне використання нових методів і прийомів; формувати в учнів стійкий інтерес до пошукової дослідницької діяльності; стимулювати творчий потенціал учнів під час розв'язування нестандартних та навчально-творчих завдань. При цьому ефективність розвитку мотивації активності учнів на уроці передусім залежить від уміння педагога формувати у вихованців більш складний вид активності, збільшуючи питому вагу самостійності та творчості у пізнанні за рахунок відносного зменшення кількості репродуктивно-наслідувальних завдань.

\section{СПИСОК ВИКОРИСТАНОЇ ЛІТЕРАТУРИ}

1. Бабанский Ю. К. Оптимизация процесса обучения: методические основы / Ю. К. Бабанский. М. : Педагогика, 1982. - 192 с.

2. Виленкин Н. Метод сквозных задач в школьном курсе математики / Н. Виленкин, А. Сатволдиев // Повышение эффективности обучения математике в школах / сост. Г. Глейзер. - М. : Просвещение, 1989. C. $101-112$.

3. Груденов Я. И. Психолого-педагогические основы методики обучения математике / Я. И. Груденов. - М. : Педагогика, 1987. - 160 с.

4. Ігнатенко М. Я. Методологічні та методичні основи активізації навчально-пізнавальної діяльності учнів старших класів при вивченні математики : автореф. дис. на здобуття наук. ступеня д-ра пед. наук : спец. 10.00.02 / М. Я. Ігнатенко ; НПУ ім. М. П. Драгоманова. - К., 1997. - 47 с.

5. Розвиток пізнавальної активності на уроках математики. URL: https://naurok.com.ua/stattya-rozvitokpiznavalno-aktivnosti-na-urokah-matematiki-133289. html (дата звернення: 20.11.2019).

6. Словарь, справочник по педагогике / под. ред. П. И. Пидкасистого. - Москва : Сфера, 2004. - С. 14.

Дата надходження до редакиіï: 27.12.2019 p.

Володимир КОВАЛЬ, кандидат педагогічних наук,

доцент кафедри математики з методикою викладання Рівненського державного гуманітарного університету

Ангеліна НЕСЕН, студентка магістратури

Рівненського державного гуманітарного університету

\title{
ЕКОЛОГІЧНЕ ВИХОВАННЯ УЧНІВ СТАРШОЇ ШКОЛИ НА УРОКАХ МАТЕМАТИКИ
}

У статті розглядається необхідність формування екологічної освіти як нової галузі педагогічноі теорії і шкільної практики. Встановлюється, щзо дисиипліна "Математика» має безпосереднє відношення шзодо вирішення назрілих екологічних проблем завдяки математичному моделюванню. Пропонується включити деякі елементи екології та охорони природи в проходження програмних тем курсу математики на уроках в старшій школі, щзо сприятиме підвищенню інтересу учнів до предмета, поглиблен- ню математичних знань $і$ формуванню екологічних переконань школярів.

Ключові слова: екологічне виховання, екологічна культура, екологічні переконання, математичне моделювання.

В статье отмечена необходимость экологического образования как новой отрасли педагогической теории и школьной практики. Раскрыто, что дисциплина «Математика» имеет непосредственное отношение 
к решению назревших экологических проблем благодаря аппарату математического моделирования. Предложено включить некоторые элементы экологии и охраны природы в преподавание программных тем курса математики на уроках в старшей школе, что приведет к повышению интереса учеников $к$ предмету, углублению знаний и формированию экологических убеждений стариеклассников.

Ключевые слова: экологическое воспитание, экологическая культура, экологические убеждения, математическое моделирование.

The article reveals that the emergence of an information society at the beginning of the third millennium is closely linked to the processes of globalization and is characterized by radical changes that cover all spheres of human life, including the education system. The role of the teacher, who should now be not only one of the sources of knowledge, but also the manager of the educational process, has changed. A modern teacher should teach a student to acquire knowledge, apply it in practice, and work to ensure that the educational standards defined in the state standard become the property of each student, the basis for forming his personal beliefs. In recent decades, environmental education has emerged as a new field of pedagogical theory and school practice. At the same time, there are practically no works in the mathematics teaching methods related to environmental education and upbringing in modern pedagogical studies. The formation of ecological knowledge among students in the process of teaching mathematics can occur in various forms of educational and cognitive activity of students: solving tasks selected by the teacher; tasking students and solving them; performing and compiling partial search tasks (to predict the results of experiments or the effects of environmental factors, to plan research, to understand certain situations, to explain situations, to predict the possible consequences of their activities or activities of other people); writing ecological-mathematical dictates; short interesting messages in the lesson; conducting integrated lessons; conducting cognitive environmental and mathematical games and other extracurricular activities, etc. The use of the elements of ecology and nature protection proposed in the article in the course of the mathematics course in high school lessons will greatly facilitate the work of mathematics teachers and will increase the interest of students in the subject, deepen mathematical knowledge and environmental education.

Key words: ecological education, mathematical modeling, ecological beliefs.

Багато років поспіль світова спільнота опікується проблемами оточуючого середовища: умовами взаємодії живих організмів між собою та 3 довкіллям, шляхами охорони та збереження природи, впливами людської діяльності на стан різних екосистем тощо. Не може залишатися осторонь від цих проблем і система освіти. У навчальній програмі «Математика. 10-11 класи. Базовий рівень стандарту» серед компетентностей, набутих учнями старших класів, виокремлено «екологічну безпеку та сталий розвиток». Означена компетентність спрямована на формування в учнів соціальної активності, відповідальності та екологічної свідомості, готовності брати участь у вирішенні питань збереження довкілля і розвитку суспільства, усвідомлення важливості сталого розвитку для майбутніх поколінь. Тому, аби підсилити інтерес учнів до екологічних проблем та вплинути на формування екологічної свідомості i світогляду учнів, вчителю варто проаналізувати i переосмислити власний світогляд. Педагог має бути переконаним у необхідності бережливого ставлення до природи та розглядати виховання екологічних переконань в учнів як свій громадський обов'язок.

Зважаючи на означене вище, метою нашого дослідження $\epsilon$ пошук шляхів та засобів формування екологічних переконань учнів на уроках математики в старших класах закладів загальної середньої освіти.

Аналіз наукових досліджень та публікацій. Проблеми сутності екологічної культури досліджували такі вітчизняні науковці, як М. Бойчева, А. Горєлов, О. Гриб'юк, С. Дерябо, Є. Король, С. Лебідь, О. Леонтьєв, І. Павленко, О. Плахотнік, Н. Пустовіт та ін. Водночас означене питання розглядали і зарубіжні вчені: К. Бредлі (Мічиганський університет, США), М. О’Коннор (Пенсільванія, США), Х. Четін (Туреччина), Д. Їлмаз (Туреччина), Г. Фернандес (Аргентина), А. Асланов (Уральський університет, Росія), А. Еркол (Туреччина) та ін.

При цьому Н. Пустовіт трактує екологічну культуру як сукупність таких елементів, як знання, вміння, почуття; структурних елементів більш високого рангу: переконань, ідеалів, відносин, вважаючи при цьому, що вони знаходяться в тісному взаємозв'язку [4]. С. Король зі свого боку розглядає екологічну культуру як якість особистості, що є основою i кінцевим результатом виховання, та тлумачить ऑї як показник такого рівня свідомості, який спонукав би підростаюче покоління до глибокого вивчення законів природи та екологічно доцільної взаємодії з нею, відображав би відповідні відносини і призводив до певних змін у природному середовищі [3].

Варто зауважити, що екологічна культура починається з екологічного виховання. За сучасним визначенням, екологічне виховання - це система виховних заходів, спрямованих на формування в членів суспільства екологічної культури, гуманності, науково обгрунтованого відношення до природи як до вищої національної і загальнолюдської цінності [5, с. 265]. В основі побудови системи екологічного виховання психологічна наука вбачає принцип А. Леонтьєва [2, с. 277], згідно з яким свідомість особистості породжується діяльністю. Натомість у дослідженні О. Гриб'юк зазначається, що більшість учителів відчувають труднощі 3 підбором повідомлень природоохоронної спрямованості та вагаються у виборі методів навчання, що несуть найбільший потенціал виховного впливу на учнів [1, с. 132].

Культурні цінності формуються завдяки вихованню - систематичним і цілеспрямованим впливам на особистість. У зв'язку з цим екологічне виховання необхідно впроваджувати під час проведення уроків та заходів із будь-якого предмета, зокрема й математики. Так, на уроках математики екологічне виховання учнів можна реалізувати в таких напрямах:

- розкриття математичних закономірностей природи через вступні бесіди вчителя згідно з темою уроку;

- з'ясування ролі математики у вирішенні екологічних проблем; 
- складання графіків і діаграм, які ілюструють функціональні залежності результатів впливу людської діяльності на природу;

- аналіз прикладів економного та ефективного використання природних ресурсів;

- розкриття математичних закономірностей певних явищ природи;

- виховання екологічного розуміння та екологічної культури, відповідальності за стан навколишнього середовища;

- розв'язання задач із метою розуміння окремих екологічних понять, обробка статистичного матеріалу [1, с. 38].

Дисципліна «Математика» безпосередньо пов'язана із розв'язанням назрілих екологічних проблем завдяки математичному моделюванню, що є основою пізнання людиною навколишнього світу. Під час експериментів, теоретичних досліджень та при обговоренні власних дій, намірів, висновків ми практично займаємося процесом моделюванням. Цілі, задачі, засоби й методи моделювання в цих випадках значно відрізняються, однак загальна спрямованість залишається єдиною - отримання нового знання шляхом випробування (дослідження) деякого замінника реального об'єкта дослідження - моделі. Розв'язування задач здійснюється за спрощеною схемою математичного моделювання, що реалізується через послідовність таких етапів:

1. Попередній аналіз об'єкта дослідження.

2. Побудова моделі.

3. Аналіз моделі математичними методами.

4. Аналіз отриманих результатів та їх перенесення на образ, що вивчається.

Кожному вчителеві необхідно творчо підходити до процесу формування вмінь математичного моделювання. Доцільним при цьому буде дотримання таких методичних рекомендацій [1, с. 158]:

- відпрацювання етапів діяльності математичного моделювання варто здійснювати за спрощеною евристичною схемою;

- узгодженість дій учителів: розпочинати роботу одночасно або з невеликими відривами в часі розв'язування тренувальних вправ на відпрацювання етапів схеми математичного моделювання;

- неперервність у навчанні математичного моделювання (зміст навчального матеріалу сприяє тому, що прикладні задачі можна розв'язувати майже на кожному занятті);

- засвоєння учнями спрощеної евристичної схеми діяльності математичного моделювання та набуття вмінь їі застосування в процесі розв'язування тренувальних і розвиваючих задач.

Розглянемо зразок задачі, на якій доречно відпрацьовувати етапи вищеозначеної схеми, розглядаючи їх у діалектичній єдності і чіткій послідовності, сприяючи засвоєнню цілого (схеми) через засвоєння його частин (етапів) [2, с. 115].

Тема. Операції над векторами.

Обчислити, яку роботу виконує очищувальна система, працюючи із силою F $(3 ;-2 ;-5)$, коли точка iï прикладання, рухаючись прямолінійно, переміщується 3 положення А $(2 ;-3 ; 5)$ у положення B $(3 ;-2 ;-1)$.

Розв 'язання (за етапами евристичної схеми):

1. Попередній аналіз об'єкта дослідження. Із курсу фізики відомо, що робота дорівнює скалярному добутку двох векторів - сили та переміщення.
Сила $\vec{F}$ задана своїми координатами в прямокутній декартовій системі координат, вектор переміщення знайти легко: як відомо з умови задачі, це вектор $\overrightarrow{A B}$

2. Побудова моделі. Якщо роботу позначимо буквою $A$, а вектор $\overrightarrow{A B}$ через $\vec{s}$, то $A=F \cdot s$.

Отже, слід знайти скалярний добуток двох векторів $(\vec{F}, \vec{s})$, заданих своїми координатами.

3. Реалізація моделі математичними методами. Скалярний добуток двох векторів, заданих своїми координатами, дорівнює сумі добутків відповідних координат цих векторів. Звідси, якщо:

$\vec{F}(3 ;-2 ;-5), \vec{s}(3-2 ;-2-(-3) ;-1-5), \vec{s}(1 ; 1 ;-6)$,

то $A=3 \cdot 1+(-2) \cdot 1+(-5) \cdot(-6)=3-2+30=31$.

4. Аналіз отриманих результатів та їх перенесення на образ, що вивчається. Сила вимірюється в ньютонах, переміщення - у метрах, робота - у Джоулях. Зважаючи на це, шукана робота дорівнює 31 Дж.

У Державному стандарті базової і повної загальної середньої освіти (освітня галузь «Математика») запропоновано теми, при вивченні яких у старших класах доцільно розв'язувати прикладні задачі екологічного змісту $[1 ; 5]$. Нижче наведемо приклади деяких із них.

Алгебра і початки аналізу

Тема. Похідна та ї̈ застосування.

Задача 1. Потрібно виготовити закритий розширювальний бак для системи центрального опалення у формі прямокутного паралелепіпеда 3 об’ємом $V$ і висотою $H$. Якою має бути основа цього бака, щоб витрати матеріалу на його виготовлення були щонайменшими?

Задача 2. Для здоров'я людини освітлення кімнати відіграє дуже важливу роль. На якій висоті $h$ від горизонтальної площини слід розмістити електричну лампу, щоб точка $A$ цієї площини була освітленою найбільше? (Освітленість у деякій точці прямо пропориійна косинусу кута падіння променів та обернено пропориійна квадрату відстані від точки до джерела світла).

Тема. Показникова та логарифмічна функиії.

Задача 3. Бактерія, потрапивши в живий організм, наприкінці 20-ї хвилини ділиться на дві (кожна 3 них ділиться знову на дві наприкінці наступних 20-и хвилин і т. д.). Визначте кількість бактерій, що утворяться з однієї до кінця доби.

Задача 4. Щорічний приріст відходів на збиткових підприємствах становить $10 \%$. Через скільки років кількість відходів збільшиться в два рази?

Тема. Інтеграл та його застосування.

Задача 5. Знайдіть площу поперечного каналу для зрошування висотою 0,6 м і шириною 1 м, що має форму параболічного сегмента.

Задача 6. Для підгодовування звірів узимку склали копицю сіна у вигляді прямого кругового циліндра 3 конічним верхом. Довжина кола основи циліндра - 20,5 м, висота копиці - 3,2 м, а висота циліндричної частини -2 м. Знайдіть масу заготовленого сіна, якщо його густина $0,03 \Gamma / \mathrm{M}^{3}$.

Тема. Елементи комбінаторики, теорії ймовірностей і математичної статистики.

Задача 7. Ймовірність того, що з узятої навмання зернини виросте колос, який матиме не менше 50-и зерен, дорівнює 0,6 . Визначте ймовірність того, що 3 узятих навмання 10-и зерен виросте хоча б один колос, який матиме не менше 50-и зернин. 
Задача 8. Членами учнівського лісництва перевіряється шість типів мінеральних добрив. 3 цією метою їм необхідно провести декілька дослідів щодо вивчення загального впливу будь-якої трійки добрив. Для кожного досліду береться ділянка площею 0,25 га. На якій площі проводитиметься все дослідження?

Геометрія

Тема. Паралельність прямих і площин у просторі.

Задача 9. Канал із трикутним перерізом глибиною 2,8 м перегороджено щитом, який має форму рівностороннього трикутника. Щоб визначити гідростатичний тиск на перегородку, необхідно знайти іiі площу. Обчисліть площу трикутного щита, якщо його розміщено вертикально.

Задача 10. Для збереження овочів було побудовано підвал у формі півциліндра. У ньому необхідно поставити два стояки, основи яких мають бути однаково віддаленими (по підлозі) від найближчої стінки і знаходитися на відстані 2 м один від одного. Визначити висоту стояків, якщо відомо, що ширина підвалу становить 4,6 м.

Тема. Об'єми та площі поверхонь геометричних тіл.

Задача 11. Щорічно до Світового океану потрапляє до 10 млн тонн нафти. Визначте об'єм цього забруднювача та вирахуйте, скільки морської води при цьому позбувається кисню, якщо один літр розлитої нафти перекриває доступ кисню до 40 тисяч літрів морської води.

Задача 12. Одна тонна нафти вкриває плівкою шість квадратних кілометрів поверхні океану. Визначте товщину утвореної плівки.

Представлені задачі можуть бути використані у процесі розробки нових підручників із математики для учнів 10-11 класів 33СО, а також методичних i навчальних посібників для вчителів.

Як засвідчує практика, для формування відповідального ставлення до навчання важливою необхідною умовою є позакласні заходи, на яких учні не лише використовують математичні знання, а й дізнаються нову інформацію, вчаться аналізувати і шукати вихід зі складної проблемної ситуації. Провівши коротку бесіду, учитель пропонує старшокласникам конкретну задачу i, в разі іiі розв'язання, намагається обов'язково вказати, яким чином сьогодні можна вирішити певну екологічну проблему [1, с. 132]. Для прикладу, розглянемо елемент бесіди на тему «Атмосферне повітря».

Проблема чистого повітря - сьогодні одна 3 найактуальніших. Щороку на планеті спалюється близько трьох мільярдів тонн вугілля, при цьому в атмосферу потрапляє 225 тисяч тонн миш'яку, 223 тисячі тонн германію, 183 тисячі тонн кобальту та 204 тисячі тонн урану. Вчені підрахували, що для нормального життя в промисловому місті на одну людину має припадати 25 кубічних метрів зелених насаджень. Вдало регулюють температуру повітря окремих ділянок земної поверхні (влітку - знижують, а зимою навпаки - підвищують) полезахисні смуги. При цьому вони зменшують випаровування вологи з поверхні грунту на $40 \%$ і швидкість вітру на $50 \%$ [1, с. 121].

Задачі для розв'язування:

1. Встановлено, що один гектар лісу очищає за рік 18 мільйонів кубічних метрів повітря. Скільки ку- бічних метрів очистить ліс площею 50 гектарів, 250 гектарів, 500 гектарів?

2. Підраховано, що над площею одного квадратного кілометра зелених насаджень збирається пилу на 50 тонн менше ніж над такою самою площею поля. На скільки менше пилу міститься над 10 га лісонасаджень ніж над такою ж площею поля?

3. Скільки вуглекислого газу вбирають зелені насадження парку площею 3,5 гектара і скільки при цьому буде виділено кисню, якщо один гектар зелених насаджень вбирає за добу 280 кг вуглекислого газу, виділяючи при цьому 220 кг кисню?

Розв'язуючи математичні задачі екологічного змісту з різними наборами даних, учні не лише удосконалюють знання $з$ математики, а й набувають природоохоронних умінь та навичок, якими керуються у своїй подальшій життєдіяльності.

Висновок. Отже, приділення значної уваги екологічному вихованню, застосуванню методики формування екологічних переконань учнів старшої школи на уроках математики відображається не лише на якості знань із математики, але й на стані екологічних знань школярів і мотивації їх природоохоронної діяльності, вмінні створювати математичні моделі (зокрема екологічного змісту), дослідженні та всебічному аналізі методів їх розв'язування. Запропоновані у статті задачі та методичні поради щодо використання елементів екології та охорони природи у процесі вивчення програмних тем із математики в старшій школі, на нашу думку, неабияк допоможуть у роботі вчителів математики, сприятимуть підвищенню інтересу учнів-старшокласників до предмета та формуванню їхніх екологічних переконань.

\section{СПИСОК ВИКОРИСТАНОЇ ЛІТЕРАТУРИ}

1. Гриб'юк О. О. Математичне моделювання як засіб екологічного виховання учнів у процесі навчання математики в класах хіміко-біологічного профілю : навчально-методичний посібник для учителів / О. О. Гриб'юк. - Рівне : РДГУ, 2006. - 202 с.

2. Леонтьев А. Н. Деятельность. Сознание. Личность / А. Н. Леонтьев. - М. : Политиздат, 1977. Изд. 2-е. -304 с.

3. Король О. В. Формування екологічної культури учнів V-VI класів у процесі вивчення інтегративного курсу «Навколишній світ» : автореф. дис. на здобуття наук. ступеня канд. пед. наук : спец. 13.00.03 «Корекційна педагогіка» / О. В. Король. - К., 1999. $19 \mathrm{c}$.

4. Пустовит Н. А. Экологическое воспитание школьников в процессе обучения сельскохозяйственному труду : автореф. дис. на соиск. ученой степени канд. пед. наук : спец. 13.00.01 «Общая педагогика, история педагогики и образования» / Н. А. Пустовит. K., 1989. $-24 \mathrm{c}$.

5. Яценко В. С. Особливості формування системи еколого-виховної діяльності учнів загальноосвітніх навчальних закладів / В. С. Яценко // Проблеми сучасного підручника : зб. наук. праць. - К. : Педагогічна думка, 2013. - Вип. 13. - С. 262-268.

Дата надходження до редакиії: 28.11.2019 p. 